\title{
El ácido úrico elevado en sangre se asoció con una mayor mortalidad cardiovascular
}

Serum Uric Acid and Cardiovascular Mortality. The NHANES I Epidemiologic Follow -up Study, 1971-1992. Fang J, Alderman M. JAMA 2000;238:240410.

Objetivo

Determinar la asociación de los niveles de ácido úrico en plasma con la mortalidad cardiovascular.

\section{Diseño}

Estudio transversal poblacional (National Health and Nutrition Examination Survey I, NHANES I) y datos epidemiológicos de seguimiento (NHANES I Epidemiologic follow up study, NHEFS)

Lugar

Población general de EE.UU.(1971-1975)

\section{Pacientes}

La muestra del estudio NHANES I fue de 20729 personas. Se evaluaron en forma detallada 6913 personas, y se incluyeron 5926 en el análisis. Se excluyeron aquellas con antecedentes cardiovasculares, gota, embarazo o ácido úrico no determinado. Edad promedio 48.1 años, ácido úrico promedio $5.49 \mathrm{mg} \%$.

\section{Evaluación de factores pronósticos}

Se realizaron mediciones de ácido úrico plasmático por un método estandarizado. Otras variables clínicas se obtuvieron a partir del cuestionario y de la historia clínica basal: tensión arterial, diabetes, enfermedad cardíaca, hipertensión, uso de fármacos, tabaquismo, ciclo menstrual, embarazo y gota.

\section{Medición de resultados principales}

Los resultados evaluados fueron: mortalidad total, cardiovascular y por cardiopatía isquémica. Fuentes de información: entrevistas, registros médicos y certificados de defunción.

\section{Resultados principales}

Los niveles mayores de ácido úrico se asociaron con: sexo masculino, edad, raza negra, tensión arterial, nivel de colesterol, IMC (índice de masa corporal), creatinina, uso de diuréticos y alcohol. El seguimiento promedio fue de 16.4 años. Se observaron 1593 muertes, 731 de causa cardiovascular (45.9\%). La mortalidad cardiovascular fue de 7.5 por 1000 pacientes/año. Los niveles elevados de ácido úrico se asociaron con mayor mortalidad cardiovascular en ambos sexos. Ajustados* por raza y edad, el cuartilo superior de ácido úrico $(>7 \mathrm{mg} \%)$ presentó mayor riesgo de muerte por cardiopatía isquémica que el cuartilo inferior $(<5.3 \mathrm{mg} \%)$ : en hombres RR 1.77 (IC 95 1.08-3.98) $p=0.002$, IRA* 0.003 (0.0010.005 ), en mujeres: RR 3 (IC $951.45-6.28$ ) $p<0.001$, IRA* 0.004 (0.003-0.006). En un análisis multivariable, ajustado* por edad, raza, IMC, nivel de colesterol, tabaquismo, alcohol, historia de hipertensión o diabetes y uso de diuréticos, el aumento de los niveles de ácido úrico se asoció de manera independiente con la mortalidad cardiovascular y por cardiopatía isquémica. Por cada $\mathrm{mg} \%$ de aumento en el ácido úrico en los hombres, RR 1.09 (1.02-1.18) y 1.17 (1.06-1.28); y en las mujeres RR: 1.26 (1.16-1.36), 1.30 (1.17-1.45), respectivamente para mortalidad cardiovascular y por cardiopatía isquémića. El exceso de riesgo se observó en toda la población, excepto en hombres con uno o más factores de riesgo cardiovascular.

\section{Conclusión}

Estos resultados sugieren que los niveles elevados de ácido úrico están asociados de forma independiente y significativa con la mortalidad cardiovascular.

\section{Comentario}

Muchos estudios epidemiológicos sugirieron al ácido úrico como un factor de riesgo cardiovascular. 1-6 $^{1-}$ Los niveles elevados de ácido úrico se asocian a obesidad, dislipidemia, hipertensión y resistencia a la insulina. Sin embargo, el rol especifico del ácido úrico y su valor pronóstico independiente no está claro. En un reporte previo de este mismo estudio, ${ }^{3}$ el ácido úrico fue un predictor independiente de mortalidad y cardiopatía isquémica solamente en mujeres. Los hallazgos de este estudio son consistentes con otros estudios previos que sugieren que el ácido úrico es un factor de riesgo independiente para mortalidad cardiovascular en la población general. En un reporte reciente del estudio Framingham, 7 el ácido úrico no fue un predictor independiente de mortalidad cardiovascular. Los resultados diferentes podrian explicarse por diferencias en la población estudiada: en el estudio Framingham la población presentaba menor riesgo de mortalidad general y cardiovascular, era casi exclusivamente blanca, y más joven. Los autores rescatan la validez interna de ambos estudios, pero remarcan que la validez, externa del estudio NHANES I sería mayor que el Framingham.

La población incluida en este estudio representa a la población general de EE.UU., dado que se seleccionó al azar una muestra del total de la población, aunque pudo existir sesgo de selección (se excluyeron pacientes por datos faltantes y pérdidas de seguimiento). Este estudio tiene muchos elementos a favor (buenas fuentes de información tanto para los factores pronósticos como para la mortalidad; un análisis tomando en cuenta las variables confundidoras*; un gran número de eventos; un seguimiento prolongado; y un punto final "duro" [mortalidad] ). Pero también tiene puntos débiles (entre otros no se detallan las pérdidas de seguimiento; falta de información y ajuste sobre otras variables importantes [ej. glucemia de ayunas]; y las limitaciones del certificado de defunción para clasificar causas de muerte).

No existe evidencia que el ácido úrico sea causal de enfermedad cardiovascular. Aunque algunos elementos pueden apoyar esta hipótesis (relación "dosis"-respuesta, fuerza de la asociación) no está claro su mecanismo biológico de acción (podría favorecer la agregación plaquetaria y la respuesta inflamatoria), y si intervenciones que reducen el ácido úrico reducen la incidencia y mejoran el pronóstico de la enfermedad cardiovascular. A pesar que la medición del ácido úrico puede agregar información pronóstica en relación al riesgo de muerte cardiovascular (fundamentalmente en pacientes sin otros factores de riesgo convencionales) no existe evidencia sobre una intervención específica que reduzca el riesgo en pacientes con ácido úrico elevado que justifique su medición rutinaria en pacientes de la población general.

Dr. Daniel Ferrante [ Cardiólogo. Clínica y Maternidad Suizo-Argentina. ]

\footnotetext{
Referencias

1 Fessel WJ. High uric acid as an indicator of cardiovascular disease. Independence from obesity. Am J Med 1980;68(3):401-404.

2 Klein R, Klein BE, Cornoni JC, Maready J, Cassel JC, Tyroler HA. Serum uric acid. Its relationship to coronary heart disease risk factors and cardiovascular disease, Evans County, Georgia. Arch Intern Med 1973; 132(3):401-410.

3 Freedman DS, Williamson DF, Gunter EW, Byers T. Relation of serum uric acid to mortality and ischemic heart disease. The NHANES I Epidemiologic Follow-up Study. Am J Epidemiol 1995; 141 (7):637644

4 Nakanishi N, Tatara K, Nakamura K, Suzuki K. Risk factors for the incidence of hyperuricaemia: a 6-year longitudinal study of middle-aged Japanese men. Int J Epidemiol 1999; 28(5):888-893. 5 Moriarity JT, Folsom AR, Iribarren C, Nieto FJ, Rosamond WD. Serum uric acid and risk of coronary heart disease: Atherosclerosis Risk in Communities (ARIC) Study. Ann Epidemiol 2000; 10(3):136143

6 Liese AD, Hense HW, LoweI H, Doring A, Tietze M, Kell U. Association of serum uric acid with all-cause and cardiovascular disease mortality and incident myocardial infarction in the MONICA Augsburg cohort. World Health Organization Monitoring Trends and Determinants in Cardiovascular Diseases. Epidemiology 1999; 10(4):391-397.

7 Culleton BF, Larson MG, Kannel WB, Levy D. Serum uric acid and risk for cardiovascular disease and death: the Framingham Heart Study [see comments]. Ann Intern Med 1999; 131 (1):7-13.
} 